\title{
OBSERVATIONS ON THE CARRIAGE OF PNEUMOCOCCI BY PATIENTS WITH CHRONIC BRONCHITIS, AND THEIR FAMILIES
}

\author{
By MARJORIE CLIFTON, M.B., CH.B., \\ *MARGARET POWNALL, M.B., Ch.B., D.P.H. \\ AND C. H. STUART-HARRIS, M.D., F.R.C.P. \\ Department of Medicine, University of Sheffield \\ * Public Health Laboratory Service \\ WITH THE ASSISTANCE OF:
}

RHINEDD HAMMOND, M.B., Сh.B. and CHRISTINE ALLOTT, B.Sc. Department of Medicine, University of Sheffield

Previous workers (Stuart-Harris, Pownall, Scothorne \& Franks, 1953; May, 1953) have reported studies on the bacterial flora of the sputum in cases of chronic bronchitis. Both pneumococci and Haemophilus influenzae have been reported frequently in the sputum but the source of these organisms, which might be either the patient's own upper respiratory tract or the environment, has not been traced. A long-term study of individuals with and without chronic bronchitis and of their families was therefore begun in an attempt to discern the role of exogenous infection in this disease. Observations were limited to the pneumococcus because serological identification of individual strains was readily possible in this species.

\section{METHODS}

Twenty-four families were studied altogether between December 1951 and February 1954, the first fifteen families being studied during 1952. Thirteen of these and nine more were observed during 1953. Two patients from the original fifteen families died during the first year of study. Thirteen patients with chronic chest disease were selected from patients attending hospital or from men who had volunteered for examination in the course of a field study of a large works near Sheffield (Stuart-Harris, 1954). The diagnosis was chronic bronchitis and emphysema in six, chronic bronchiectasis and emphysema in five, and pulmonary heart failure secondary to chronic bronchitis or bronchiectasis in two. Eleven volunteers, all healthy men free from chest or other disease, were selected in the same field study, and the families of these are hereafter referred to as group $\mathrm{A}$. The families of the patients with chronic bronchitis are referred to below as group B. Group A contained 45 individuals including 20 children under 15 years of age. Group B consisted of 54 individuals including 19 children aged 15 years or less. The men in group A averaged $36 \cdot 3$ years of age in 1953 (range $32-44$ ), whereas those in group $B$ averaged 50.4 years (range 45-66). The social and geographical conditions of the two groups of families were similar, but all the men in group A were at work, 
whereas five of the patients with chronic bronchitis had retired or had been disabled by chest disease.

The study consisted of the examination of nasopharyngeal swabs for pneumococci, by mouse inoculation, at intervals of 4-6 weeks. Sputum from the men with chronic bronchitis was similarly examined on each occasion and details were obtained when the family was visited of all illnesses which had occurred since the previous visit. From six to fourteen observations were made on each of the various families during the study.

\section{The pneumococcus carrier-rate}

Pneumococci were recovered from all but six persons in group A and all but eight persons in group B. All but two of those with negative swabs were adults and there were thus thirty-nine persons in group A and forty-six in group B who were shown at least once to be carrying pneumococci.

\section{Table 1. Pneumococcal swab-rates in the two groups of families}

\begin{tabular}{|c|c|c|c|c|c|c|}
\hline & \multicolumn{3}{|c|}{ Group A } & \multicolumn{3}{|c|}{ Group B } \\
\hline & $\begin{array}{c}\text { No. } \\
\text { swabs } \\
\text { positive }\end{array}$ & $\begin{array}{l}\text { Total } \\
\text { swabs }\end{array}$ & $\begin{array}{c}\% \\
\text { positive }\end{array}$ & $\begin{array}{c}\text { No. } \\
\text { swabs } \\
\text { positive }\end{array}$ & $\begin{array}{l}\text { Total } \\
\text { swabs }\end{array}$ & $\begin{array}{c}\% \\
\text { positive }\end{array}$ \\
\hline $\begin{array}{l}\text { Volunteers or patients and families } \\
\text { together }\end{array}$ & 141 & 378 & 37 & 213 & 520 & 41 \\
\hline $\begin{array}{l}\text { Volunteers or patients alone (swabs } \\
\text { in group A, 'visits' in group B) }\end{array}$ & 27 & 96 & 28 & 112 & 142 & 80 \\
\hline Group B patients-swabs & - & - & - & 59 & 134 & 44 \\
\hline Group B patients-sputum & - & - & - & 105 & 136 & 77 \\
\hline $\begin{array}{l}\text { Families, excluding volunteers or } \\
\text { patients }\end{array}$ & 114 & 282 & 40 & 154 & 386 & 40 \\
\hline Wives & 22 & 97 & 23 & 26 & 119 & 22 \\
\hline Children under 15 years & 82 & 164 & 50 & 91 & 153 & 59 \\
\hline Others, 15 years and over & 9 & 21 & 43 & 37 & 114 & 33 \\
\hline
\end{tabular}

Table 1 gives the summarized results of the positive swab-rates for different members of the families and shows that closely similar carrier-rates were found in the two groups of families excluding the volunteers. The gross carrier-rate of $40 \%$ agrees with that found by other workers. Thus Straker, Hill \& Lovell (1939), in the most comprehensive observations of the nasopharyngeal flora in Great Britain yet made, found a rate varying from 20 to $60 \%$. The type of residential community which was studied affected the results. In military communities a widely fluctuating but high rate has often been recorded, but many of these observations were made in communities with a high incidence of pneumonia. Recent family studies in Paddington (Mendez \& Likar, 1953) and in Glasgow (Landsman, 1953), have yielded results of a similar order to our own. Both observers noted a higher rate of carriage in the children than in adults, and children under fifteen in both of our own groups of families exhibited carrier-rates of $50 \%$ or more.

The healthy volunteers in the group A families exhibited a similar carrier-rate $(28 \%)$ to that of their wives $(23 \%)$, but the patients with chronic chest disease 
differed from their families and from all other persons. $44 \%$ of the 139 nasopharyngeal swabs from these men were positive and $77 \%$ of 136 specimens of sputum yielded pneumococci. Considering the results obtained on actual visits with either type of specimen, $80 \%$ of visits yielded pneumococcal isolations from these men. It is clear that a simple study of the pneumococcal carrier-rates suggests that the only difference between the two groups of families is the abnormally high rate of carriage of pneumococci in the men with chronic chest disease.

\section{Acute respiratory infections and the detection of pneumococci}

The majority of recorded respiratory infections in the families were common colds, but sporadic cases of influenza, tonsillitis, laryngitis, tracheitis, bronchitis, pneumonia and pleurisy also occurred. The total number of incidents was lower than that recorded in other studies recently (Badger, Dingle, Feller, Hodges, Jordan \& Rammelkamp, 1953) perhaps because of the relatively long intervals between visits and the small number of pre-school children in the present families. A wide range of variation was found between families and between members of families. For the sake of comparison, the number of infections was calculated per person over 10-month periods (the shortest period of study of any one individual). That in the group A families was 1.9, in the healthy group A men (volunteers) $\mathbf{1 \cdot 6}$, and in members of group B families excluding the patients $0 \cdot 8$. The group B patients suffered several attacks of bronchitis as well as other minor infections and for them the total figure was 2.5 per person per 10 months.

Table 2. Pneumococcal isolations (a) in the presence, $(b)$ in the absence of acute respiratory infection at the time of swabbing

\begin{tabular}{|c|c|c|c|c|c|c|c|c|c|}
\hline & \multirow[b]{2}{*}{$\begin{array}{l}\text { No. of } \\
\text { persons }\end{array}$} & \multicolumn{4}{|c|}{ Respiratory infection present } & \multicolumn{4}{|c|}{ Respiratory infection absent } \\
\hline & & $\begin{array}{l}\text { Total } \\
\text { swabs }\end{array}$ & $\begin{array}{l}\text { No. } \\
\text { positive }\end{array}$ & $\begin{array}{c}\% \\
\text { positive }\end{array}$ & $\begin{array}{l}\text { No. and \% } \\
\text { total swabs } \\
\text { yielding } \\
\text { 'new' types }\end{array}$ & $\begin{array}{l}\text { Total } \\
\text { swabs }\end{array}$ & $\begin{array}{l}\text { No. } \\
\text { positive }\end{array}$ & $\begin{array}{c}\% \\
\text { positive }\end{array}$ & $\begin{array}{l}\text { No. and \% } \\
\text { total swabs } \\
\text { yielding } \\
\text { 'new' types }\end{array}$ \\
\hline $\begin{array}{l}\text { Group A, volunteers } \\
\text { Group A, families }\end{array}$ & $\begin{array}{l}11 \\
34\end{array}$ & $\begin{array}{l}20 \\
64\end{array}$ & $\begin{array}{r}7 \\
25\end{array}$ & $\begin{array}{l}35 \\
39\end{array}$ & $\begin{array}{l}4(20) \\
9(14)\end{array}$ & $\begin{array}{r}76 \\
218\end{array}$ & $\begin{array}{l}20 \\
89\end{array}$ & $\begin{array}{l}26 \\
41\end{array}$ & $\begin{array}{l}13(17) \\
39(18)\end{array}$ \\
\hline Total group A & 45 & 84 & 32 & 38 & $13(15)$ & 294 & 109 & 37 & $52(17)$ \\
\hline $\begin{array}{l}\text { Group B, families* } \\
\text { Group B, patients } \dagger\end{array}$ & $\begin{array}{l}33 \\
10\end{array}$ & $\begin{array}{l}32 \\
29\end{array}$ & $\begin{array}{l}16 \\
23\end{array}$ & $\begin{array}{l}50 \\
79\end{array}$ & $\begin{array}{l}9(28) \\
3(10)\end{array}$ & $\begin{array}{r}289 \\
84\end{array}$ & $\begin{array}{r}129 \\
70\end{array}$ & $\begin{array}{l}45 \\
83\end{array}$ & $\begin{array}{l}45(15) \\
22(26)\end{array}$ \\
\hline Total group $B$ & 43 & 61 & 39 & 64 & $12(20)$ & 373 & 199 & 53 & $67(18)$ \\
\hline
\end{tabular}

* Nine families only because information concerning infection was inadequate in the other four.

$\dagger$ Figures refer to results on sputum and swabs and not to swabs alone.

No close association existed between the positive swab-rate and the number of respiratory infections in the various families. Furthermore, considering only those infections which were found to be present at the time of swabbing, the carrier-rate in group A families was uninfluenced by such infections. Thus $38 \%$ of swabs taken during minor infections in group A families yielded pneumococci compared with $37 \%$ positive swabs in the absence of infection (Table 2). However, Table 2 shows a difference in swab-rate in group A volunteers and also in the group B families 
according to whether an infection was or was not present at the time of swabbing. Thus $35 \%$ of swabs from group A volunteers were positive during infections compared with $26 \%$ during normal health, and $64 \%$ of swabs from group B families were positive during infections compared with $53 \%$ in the absence of infection. The difference in incidence in the group $B$ families was wholly accounted for by the experience in the members other than the patients. The high rate of carriage of the latter was uninfluenced by minor infections. Fifteen of the twenty-nine observed infections in the group B patients were considered to be attacks of bronchitis so that the finding of the same rate of carriage of pneumococci whether or not acute exacerbation of symptoms existed seems to have been established.

It is difficult to know whether the relatively minor variations in the carrier-rates at times of respiratory infection in the group A volunteers and members of group B families are of significance. Other workers recently have noted a similar increase in pneumococcal carrier-rate at times of minor infection (Landsman, 1953; Mendez \& Likar, 1953), but this was not observed by Straker et al. 1939, or by Finland (1942) who felt that the presence of upper respiratory infections was not ordinarily a determining factor in the incidence of pneumococcus carriage.

\section{Types of pneumococci isolated from both groups of families}

The pneumococci isolated from the population under study were typed serologically, using typing sera obtained from the State Serum Institute, Copenhagen. By this, it was hoped to obtain evidence concerning the types simultaneously present in the patient with chronic bronchitis and other members of the family, and also to learn whether acquisition of a new type by the patient was related to exacerbations of symptoms. It was hoped also that the order of acquisition of types by members of the families might indicate whether the patient was infected exogenously from his family or vice versa.

The range of types isolated from the families was wide, but much the same types were concerned in both groups. Types $6,3,35$ and 22 were recovered most frequently from group A families, and types $6,19,15,3,9$ and 18 were the commonest types in group B. The group B patients harboured types 3,6 , and 35 most frequently in both swabs and sputum. The duration of carriage of the same type of pneumococcus by any one individual varied within wide limits. Among the volunteers in group $A$, the same type of pneumococcus persisted for up to 2 months in five instances involving four men. Members of group A families carried the same organism for from 2 to 8 months in twenty-four instances affecting twenty people. The members of group $B$ families carried the same organisms for from 2 to 5 months in twenty-two instances involving seventeen people and thus did not differ from those in group A. The patients in group B, however, showed a higher incidence of prolonged carriage of the same organism. There were altogether thirty instances involving twelve men where the same organism was found on two or more successive occasions. In twenty instances the organism persisted in either sputum or swab for 2 months, and in ten instances it persisted for 3-7 months. No particular type of pneumococcus was concerned in these instances of prolonged carriage. 
Simultaneous carriage of the same types of pneumococci in more than one member of the family occurred on 25 occasions in the group A families which were visited 97 times and on 35 of 93 occasions in the group B families. But the patient in group B families was found to be carrying the same type of pneumococcus as a member of his family on 21 of the 93 visits. This must be compared with the eight occasions among 97 visits when the volunteer in group A families was found to be carrying the same organism as another member of his family. The greater frequency of simultaneous carriage of the same type of pneumococcus in the patient with chronic bronchitis and a member of his family compared with the rate found for healthy men was statistically significant $\left(\chi^{2}=6 \cdot 31,0 \cdot 02>P>0 \cdot 01\right)$.

\section{The introduction of 'new' types of pneumococci}

'New' types were considered to be ones which had not previously been found in the individual or family or which, though previously encountered in the family, had been absent from that family for one year or more before re-appearance. In considering the appearance of new types, the visits on which the volunteer himself was absent or when he alone was seen were ignored and also, of course, the first visit to any family.

\section{(a) Occurrences}

Among members of group A families, which were visited 85 times, 67 new types of pneumococci were recovered from the total of 378 swabs. The volunteers in these families yielded new types in 12 of 23 positive swabs. It frequently happened that new types appeared in more than one member of the family on one and the same occasion but there was no tendency for new types to be found on more occasions when acute respiratory infections were present in the individual than in their absence (Table 2).

Among members of the families in group B, excluding the patients, 63 new types were cultivated from a total of 386 swabs, which was similar to the proportion observed in group A. But new types were isolated more often when respiratory infections were present in the families than in their absence (Table 2). New types appeared in the patient with chronic chest disease on 32 of the 93 visits when pneumococci were isolated, being found either in the sputum alone, the swab alone, or in both swab and sputum. The proportion of new to old types of pneumococci was actually lower in these patients than in other healthy persons because of the former's higher incidence of carriage. This lower proportion was perhaps negatively correlated with the greater persistence of individual species of pneumococci in patients with chronic chest disease than in healthy persons.

Much to our surprise the discovery of a new type of pneumococcus in a man suffering from chronic chest disease was not associated with the occurrence of fresh evidence of respiratory infection except in one instance. Patient $Q$ was admitted to hospital in May 1953 with pneumonia and a Type 1 pneumococcus was found in the sputum. This organism had not been found in the family for the previous 11 months, having then been present in the son's swab on one occasion. It was not 
found after that occasion in any swab nor did it re-appear in other members of the family at the time of the case of pneumonia. Apart from this occasion, the isolation of new types of pneumococci occurred rather more frequently when the patient was not affected by an acute infection than the reverse (Table 2).

\section{(b) Spread of new types}

Among the healthy volunteers and their families, in whom new types were found in one person only on forty-seven occasions, the same type appeared at the next visit in another member of the family 5 times. The volunteer himself was neither the originator nor the recipient on any of these five occasions. When a new type first appeared in two persons simultaneously, which happened on ten visits, it spread to another person only once; in this case the volunteer was one of the originators. In group A families, therefore, it did not often happen that when a new type appeared it was passed on to other members, though the visits were widely spaced and any spread which might have taken place in which the carriage of the type was of short duration would not have been detected. An example of the spread of a new type in a group A family is shown in Table 3.

In group B families, excluding the patients, forty swabs showed new types originating in a single person. On another ten occasions a new type appeared simultaneously in two or three persons and one of these was a patient in three instances. Seven of these new types appeared at the next visit in another member of the family. The spread twice occurred from family to patient, and 5 times within the family. On one of these five occasions the patient and one daughter both showed type 22, which at the next visit was found in another daughter and in the son. On another, type 18 appeared in the son of patient $X$, spread to his two sisters at the next visit and was later found in his father and mother as well (Table 3).

Group B patients showed new types in themselves alone on twenty-nine visits. One of these was found at the next visit in the man's wife. In addition, there were two instances when a type which the patient had been carrying on two or more visits then appeared in one of the family, and four instances when a strain present in the family over a period then appeared in the patient, one of which is mentioned above. Only one such instance occurred in group A. Thus the patients in group B were concerned on four occasions in the spread of a new type, and on another six in the spread of a type already present for a time. This must be compared with one instance of each sort in group A in which the volunteer was concerned. There were, therefore, more instances of apparent spread of pneumococci in the families which included cases of chronic bronchitis but the phenomenon was still only occasional in its occurrence.

\section{DISCUSSION}

The results obtained in the families where the father or husband was a subject with chronic chest disease must be discussed using those from other healthy families as a background. The group B families were centred around patients with chronic chest disease. Pneumococci were isolated from these patients on $80 \%$ of occasions when a nasopharyngeal swab or sputum or both specimens were 
examined. This indicates an extremely high rate of carriage of these organisms, beyond the range encountered in any normal groups in this study. However, the carriage was not apparently influenced by acute respiratory episodes in the patients and the range of types of organisms recovered was similar to that found

Table 3.

Record of healthy family (volunteer $J$ ) showing the introduction and spread of type 3 pneumococcus

(Ages of children given in brackets.)

$\begin{array}{rllll}\begin{array}{c}\text { Date of visit } \\ \text { (1953) }\end{array} & \text { Volunteer } J & \text { Wife } & \text { Daughter (7) } & \text { Daughter (3) } \\ 23 \text { Feb. } & - \text { ve } & - \text { ve } & - \text { ve } & 19 \\ 15 \text { Apr. } & - \text { ve (cold) } & - \text { ve } & - \text { ve (cold) } & - \text { ve (cold) } \\ 18 \text { May } & - \text { ve (cold) } & - \text { ve (cold) } & 3 \text { (cold) } & - \text { ve (cold) } \\ 1 \text { July } & - \text { ve } & 3 & 3 & -v e \\ 17 \text { Aug. } & 17 & 3 & 3 & 3 \\ 5 \text { Oct. } & - \text { ve } & -v e & -v e & -v e \\ 7 \text { Dec. } & -v e & 11 & -v e \text { (tonsillitis) } & - \text { ve }\end{array}$

Family record of patient $X$ showing the introduction, spread and persistence of type 18

\begin{tabular}{|c|c|c|c|c|c|c|}
\hline \multirow{2}{*}{$\begin{array}{l}\text { Date of visit } \\
\quad(1953)\end{array}$} & \multicolumn{2}{|c|}{ Patient $\mathrm{X}$} & \multirow[b]{2}{*}{ Wife } & \multirow[b]{2}{*}{ Daughter (16) } & \multirow[b]{2}{*}{ Son (11) } & \multirow[b]{2}{*}{ Daughter (5) } \\
\hline & Sputum & Swab & & & & \\
\hline 22 Jan. & 6,15 & 6 & $-v e$ & $-v \theta$ & 18 & - ve (chest cold) \\
\hline 11 Mar. & 6 & - ve & - ve & 18 & 18 & 18 \\
\hline 22 Apr. & 15 & 6 & 19 & 18 & 35 & 18 \\
\hline 4 June & 18 & 6 & 18 & 18 & 18 & 18 \\
\hline 13 July & 14 & - ve (cold) & 18 & 18 & - ve & $\rightarrow$ ve \\
\hline 26 Aug. & - ve & 14 & 23 & 18 & 18 & - ve \\
\hline 13 Oct. & - ve & $-v e$ & - ve & 18 (cold) & (away) & $6(\operatorname{cold})$ \\
\hline 1 Dec. & 6 & - ve & - ve & -ve & (away) & $6,14,18$ \\
\hline
\end{tabular}

Family record of patient $Y$ showing the introduction of type 7 and its persistence in the patient's sputum

Patient $\mathrm{Y}$

\begin{tabular}{|c|c|c|c|c|c|}
\hline \multirow{2}{*}{$\begin{array}{l}\text { Date of visit } \\
\quad(1953)\end{array}$} & \multirow[b]{2}{*}{ Sputum } & \multirow[b]{2}{*}{ Swab } & \multirow[b]{2}{*}{ Wife } & \multirow[b]{2}{*}{ Son $(20)$} & \multirow[b]{2}{*}{ Son (14) } \\
\hline & & & & & \\
\hline 26 Jan. & - ve & $-v e$ & 27 & (away) & 3 \\
\hline 17 Mar. & - ve & $-v e$ & 27 & 15 (cold) & 3,7 (cold) \\
\hline 4 May & 7 & $-v e$ & $\begin{array}{c}20 \\
\text { (pleurisy) }\end{array}$ & - ve & 3 \\
\hline 6 July & 7 & $-v e$ & 27 & - ve & $-v e$ (cold) \\
\hline 10 Aug. & 7 & - ve & - ve & - ve & - ve (tonsillitis) \\
\hline 19 Sept. & 7 & $-v \theta$ & 27 & - ve & 3 \\
\hline 16 Nov. & $\mathbf{l}$ & - ve & 14 & - ve & 6 \\
\hline 15 Feb. (1954) & - ve & $-v e$ & - ve & - ve & 27 \\
\hline
\end{tabular}

in normal persons. The duration of carriage of individual types was, however, often prolonged and though new types were isolated on a greater number of the occasions when specimens were taken, the actual proportion of new to old pneumococci was less than among healthy persons. New types, moreover, occurred in the swab or sputum without apparent relation to acute respiratory episodes except in the one case of pneumonia already cited. 
All these findings could be explained by an abnormality of the individual whereby some portion of the respiratory tract was readily colonized by pneumococci. In view of the bronchoscopic observations of Brown, Coleman, Alley, Stranahan \& Stuart-Harris (1954), it may be assumed that the lower rather than the upper respiratory tract is the focus of abnormal bacterial colonisation and the relative frequency of isolation of pneumococci from swabs and sputum in the present study supports this deduction. The family studies made in relation to the patient with chronic chest disease show that the latter may acquire new types of pneumococci either simultaneously with, before or after, their appearance in other members. Studies at much closer intervals of time would be necessary to define which was the most frequent pattern of spread, and all that can be stated with assurance is that there is evidence of a closer bacterial link between patient and family, than between individual healthy adults and their families. This link indicates that cross-infection with pneumococci is a more frequent phenomenon in the family housing a patient with chronic chest infection than in healthy families. If this is so, then clearly other organisms such as $H$. influenzae, or staphylococci may also be interchanged more frequently than among normal families, but our investigation was not extended to such species.

Despite the evidence of an abnormal epidemiological situation in the families of patients with chronic bronchitis, no obvious association was found between exogenous infection and clinical events either in the patient or his family. The fact that pneumococcal types did not appear to change during acute relapses of bronchitis would seem to rule out the probability that cross-infection with new organisms was concerned in evoking relapse. However, the role of bacterial infection in chronic bronchitis has already been compared (Stuart-Harris et al. 1953 ) with that of wound infection. The unknown factors in relation to the acute exacerbation of symptoms in bronchitis may be virus infections, meteorological changes or some other disturbance. It is possible that the abnormal family epidemiological situation has the effect of sustaining bacterial infection of the lower respiratory tract rather than that of provoking fresh damage. It is clear that further study of the acute episodes in the life history of patients with chronic bronchitis is desirable.

\section{SUMMARY}

1. The pneumococcal carrier-rate in members of families of men with chronic chest disease observed over prolonged periods was of the same order $(40 \%)$ as that observed simultaneously among members of healthy families.

2. Those with chronic bronchitis or bronchiectasis with emphysema yielded pneumococci in the sputum more frequently $(77 \%)$ than in the nasopharynx $(44 \%)$. Healthy men yielded pneumococci in the nasopharynx on $28 \%$ of occasions.

3. Acute respiratory infections were not observed more frequently among members of families of men with chronic chest disease than among healthy families. The pneumococcal carrier-rate at the time of occurrence of acute infections was much the same as when infections were absent. Acute infections, including attacks of bronchitis, occurred more frequently in the men with chronic chest disease 
than in healthy men, but the pneumococcal carrier-rate at such times was unchanged.

4. The range of types of pneumococci found in men with chronic chest disease and in members of their families was similar to that observed in healthy families. Carriage of the same type of pneumococcus over prolonged periods was commoner in the men with chronic chest disease than in the healthy subjects.

5. Simultaneous carriage of the same types of pneumococcus by men with chronic chest disease and another member of the family occurred three times as frequently as simultaneous carriage in healthy families involving the father or husband.

6. 'New' types of pneumococci not previously isolated were found irrespectively of acute respiratory infections in men with chronic chest disease and in healthy men. The appearance of a new type of pneumococcus in a member of a healthy family was occasionally followed by its spread to other members. New types found in men with chronic chest disease or in members of their families appeared to spread to other members of the family or to the patient much more frequently, thus suggesting a higher incidence of cross-infection in these families.

\section{REFERENCES}

Badger, G. F., Dingle, J. H., Feller, A. E., Hodges, R. C., Jordan, W. S. G. \& RammelKAMP, C. H. Jr. (1953). Amer. J. Hyg. 58, 31 .

Brown, C. C., Jr., Coleman, M. B., Alley, R. D., Stranahan, A. \& Stuart-Harris, C. H. (1954). Amer. J. Med. 17, 478.

Finland, M. (1942). Medicine, Baltimore, 21, 307.

Landsman, J. B. (1953). Proc. R. Soe. Med. 46, 61.

MAY, J. R. (1953). Lancet, ii, 534.

Mendez, R. L. \& Likar, M. (1953). Proc. R. Soc. Med. 46, 63.

Straker, E., Hill, A. B. \& Lovell, R. (1939). Rep. Minist. Hlth, Lond., no. 90.

StUART-HaRRIS, C. H. (1954). Brit. J. Tuberc. 48, 169.

Stuart-Harris, C. H., Pownall, M., Scothorne, C. M. \& Franks, Z. (1953). Quart. J. Med., N.S., 22, 121.

(MS. received for publication 8. I. 55) 